\title{
DAMPAK KEMISKINAN INFORMASI MASYARAKAT DALAM TRANSAKSI BERBELANJA ONLINE
}

\author{
Adista Nurfitria \\ Universitas Indonesia \\ e-mail: adista.nur@ui.ac.id \\ Laksmi \\ Universitas Indonesia \\ e-mail:1laksmi706@gmail.com
}

\begin{abstract}
Abstrak:
Penelitian ini bertujuan untuk mendeskripsikan dampak kemiskinan informasi dalam transaksi berbelanja online. Metode yang digunakan dalam penelitian ini adalah pendekatan kualitatif dengan metode kajian budaya. Literatur yang terjaring dalam artikel ini sebanyak 14 artikel berita yang didapat dari portal berita online yang terbit pada tahun 2021, dan 15 literatur ilmiah dengan periode tahun terbit dari 2007-2020. Adapun hasil dari penelitian ini adanya gap tentang pengertian dari pembelian menggunakan metode pembayaran COD terjadi karena faktor minimnya pengetahuan konsumen akan transaksi berbelanja online. Selain itu kurangnya edukasi yang dilakukan oleh pihak e-commerce kepada konsumen tentang transaksi berbelanja online yang tersedia secara terperinci dan peraturan pemerintah yang belum sempurna dalam melindungi konsumen saat melakukan proses transaksi berbelanja online melalui e-commerce. Kesimpulan menunjukan, kemiskanan informasi terjadi karena adanya kesalahpahaman dari konsumen tentang pengertian metode pembayaran COD yang benar dan ideal. Saran yang dapat diberikan adalah dengan membuat konten edukasi tentang produk dan layanan yang diberikan serta menyempurnakan peraturan tentang transaksi berbelanja online.
\end{abstract}

Kata kunci: kemiskinan informasi; masyarakat informasi; e-commerce

\begin{abstract}
Abstrack:
This study aims to describe the impact of information poverty in online shopping transactions. This research was conducted by using qualitative approach with cultural studies method.. The literature collected in this article is 14 news articles obtained from online news portals published in 2021, and 15 journal articles from the year 2007-2020. In the results of this study, there is a gap regarding the understanding of purchases using the COD payment method due to the lack of consumer knowledge about online shopping transactions. In addition, there is a lack of education carried out by e-commerce parties to consumers about online shopping transactions that are available in detail and imperfect government regulations in protecting consumers when processing online shopping transactions through e-commerce. The conclusion shows that information poverty occurs because of a consumers misunderstanding about the correct and ideal regulations of the COD payment method. Suggestions that can be given are to create educational content about the products and services provided and improve regulations regarding online shopping transactions.
\end{abstract}

Keywords: information Poverty; information society; e-commerce

\section{Pendahuluan}

Kemiskinan informasi adalah salah satu bentuk utama kemiskinan di masa kini ${ }^{1}$. Kemiskinan informasi berkaitan dengan ketidakmampuan individu atau komunitas dalam mengakses informasi penting dan ketidakmampuan untuk memanfaatkan informasi sebagai upaya memenuhi kebutuhan dasar dalam bertahan hidup dan berkembang.
Kemiskinan informasi merupakan sebuah konsep yang sudah ada sejak pasca industrial, masyarakat Informasi merupakan suatu keadaan masyarakat ketika produksi, distribusi, dan manipulasi suatu informasi menjadi kegiatan utama ${ }^{2}$. Informasi menjadi produk utama sehari-hari yang digunakan oleh masyarakat. Masyarakat akan mengambil keputusan didasari oleh informasi yang diketahui 
untuk menyelesaikan permasalahan hidupnya. Contohnya saat memilih menggunakan pakaian yang akan dikenakan hari ini, masyarakat akan mengambil keputusan dari hasil ramalan cuaca yang dapat dilihat dari berita, ataupun gawai masing-masing.

Kemiskinan informasi merupakan sebuah gap atau ketimpangan yang ada di masyarakat dalam menilai dan memaknai informasi. Informasi juga mempengaruhi kemajuan teknologi yang ada di masyarakat, aplikasi belanja online atau e-commerce merupakan sebuah produk yang diimplementasikan berdasarkan informasi kebutuhan masyarakat saat ini yang ingin serba instan dan didukung oleh kemajuan teknologi membuat e-commerce sangat diterima oleh masyarakat Indonesia. Berbelanja online bukan hal yang tabu lagi bagi masyarakat Indonesia terlebih lagi masyarakat yang tinggal di perkotaan. Dengan e-commerce hampir seluruh barang dapat dicari dan dibeli, mulai dari perlengkapan pribadi sehari-hari hingga pembelian kebutuhan tersier seperti perhiasan, barang mewah (barang-barang keluaran designer) hingga kendaraan dapat dibeli melalui e-commerce. Dengan seiring berjalannya waktu dan kemajuan teknologi, masyarakat Indonesia beralih gaya membelinya yaitu berbelanja melalui e-commerce. Alasan masyarakat Indonesia beralih dari membeli dengan cara konvensional yaitu mengunjungi langsung ke toko ke berbelanja melalui e-commerce karena kemudahan dalam transaksi pembelian yang dilakukan. Kemudahan yang ditawarkan tersebut mempengaruhi niat masyarakat untuk membeli secara online. $^{3}$

Saat informasi dikemas menjadi sebuah produk, di zaman yang serba digital dan instan

'Johannes Britz, 'Information Poverty: The Development of a Global Moral', 2010, 9-17.

${ }^{2}$ Wiji Suwarno, Pengetahuan Dasar Kepustakaan (Bogor: Ghalia Indonesia, 2010).

${ }^{3}$ M.T Septianie, I. \& Wiyata, 'Pengaruh Kemudahan Dan Kepercayaan Terhadap Niat Pembelian Secara Onlinepada Platform E-CommerceLazada Indonesia.', Winter Journal., 1.1 (2020), 73-83.

${ }^{4}$ S. Hamed, S., El-Deeb, 'Cash on Delivery as a Determinant of E-Commerce Growth in Emerging Markets.', Journal of Global Marketing, 33.4 (2020), 242-265. ini e-commerce atau tempat perbelanjaan online merupakan hasil dari produk yang didasari oleh informasi, yaitu data kebutuhan masyarakat masa kini. Berbelanja online melalui e-commerce makin menjamur dan menjadi pilihan utama masyarakat untuk berbelanja kebutuhan mereka karena tidak perlu keluar rumah, hanya mengoperasikan gawai saja dan membeli kebutuhan yang diinginkan melalui e-commerce yang dipercaya lalu melakukan checkout dan transaksi pembayaran online seperti transfer via M-Banking atau pembayaran online lainnya seperti OVO, GOPAY, DANA dan lainnya.

Setelah itu, barang yang dibutuhkan akan diantarkan oleh kurir kerumah pemesan. Selain pembayaran online, e-commerce juga menawarkan pembayaran tunai dengan cara Cash on Delivery atau disingkat dengan COD. COD menawarkan metode pembayaran tunai saat barang yang dibeli diantarkan oleh kurir ke rumah konsumen. Metode pembayaran COD ini lebih diminati oleh negara berkembang, negara berkembang masyarakatnya cenderung tidak begitu mempercayai penggunaan kartu kredit. Untuk itu COD sangat perlu untuk dimasukan opsi pembayaran bersama dengan metode pembayaran lain untuk memasuki semua pasar konsumen. COD merupakan metode pembayaran belanja online yang tidak boleh dihapus, karena dapat menarik konsumen lebih luas dari berbagai kelas sosial seperti konsumen yang tidak memiliki kartu kredit, dan memberikan kemudahan dalam pembayaran perbelanjaan ${ }^{4}$. Masyarakat Indonesia juga menggunakan metode COD sebagai pembayaran perbelanjaan online mereka.

Meningkatnya minat masyarakat dalam berbelanja online dengan metode COD di Indonesia semakin tinggi di masa pandemi COVID 19 ini. Hal ini dikarenakan masyarakat dibatasi ruang

\footnotetext{
${ }^{5}$ Britz.

${ }^{6}$ Xiaobo Mou, 'Examining the Factors in Fl Uencing Information Poverty in Western China', 38.2019 (2020), 1115-34 < https://doi.org/10.1108/EL 04-2020-0095>

${ }^{7}$ I. D. Wedhaswary, '). Kasus Kurir COD Dimaki Konsumen, Apa Yang Harus Diperbaiki?', 2021.
} 
geraknya dalam melakukan aktivitas sehari-hari untuk memutus rantai virus COVID di Indonesia. Era pandemi ini menjadi faktor pergeseran budaya berbelanja secara tradisional yaitu berbelanja langsung di toko menjadi berbelanja secara daring.

Britz dalam penelitiannya yang berjudul "Information Poverty: The Development of a Global Moral" menemukan bahwa kemiskinan informasi dapat mengakibatkan timbulnya masalah moral yang serius ${ }^{5}$. Mou dalam penelitiannya yang berjudul "Examining the factors influencing information poverty in western China" menemukan bahwa literasi informasi, penyediaan informasi dan teknologi informasi dan komunikasi (TIK) berpengaruh positif dan signifikan terhadap kemiskinan informasi ${ }^{6}$. Oleh karena itu, artikel ini ingin membahas tentang kemiskinan informasi masyarakat dalam menggunakan produk TIK yaitu e-commerce.

Kemajuan TIK menciptakan budaya baru yaitu transaksi berbelanja luring menjadi daring. Selama masa peralihan budaya berbelanja luring menjadi belanja daring ini menimbulkan beberapa kasus kesalahpahaman akan tata cara berbelanja online yang benar. Hal ini dikarenakan belum meratanya pengetahuan masyarakat tentang transaksi pembelian online yang benar. Kemampuan dalam mencerna informasi dari masing-masing individu juga menjadi faktor terjadinya kesalahpahaman dalam transaksi berbelanja online. Hal ini menggambarkan kemiskinan informasi yang dimiliki oleh masyarakat dalam transaksi berbelanja online.

Banyak sekali kasus yang terjadi tentang masyarakat yang tidak puas dalam berbelanja online tapi salah dalam mengutarakan kekece-

${ }^{8}$ N. Sari, 'Pria Di Ciputat Ancam Kurir COD Dengan Pedang Karena Merasa Ditipu, Beli Jam Tapi Dapat Kardus Kosong,', Kompas.Com, 2021.

${ }^{9} \mathrm{R}$. Sihombing, 'Todong Kurir Barang Pakai Pistol, Pria Di BOGOR DITANGKAP.', 2021

${ }^{10}$ 'Viral, Emak-Emak Di Pasaman Barat Maki Kurir Belanja Online COD.', 2021.

${ }^{11} \mathrm{R}$. Sugihartati, Perkembangan Masyarakat Informasi Dan Teori Sosial Kontemporer. (Jakarta: Kencana, 2014). waannya. Kasus yang belakangan terjadi adalah pembelian online dengan pembayaran $\mathrm{COD}$. Konsumen yang tidak puas, banyak yang malah melampiaskan ketidakpuasannya kepada kurir yang bertugas menghantarkan barang kepada konsumen. Banyak sekali berita yang beredar dan menjadi viral tentang konsumen yang mengutarakan kekesalan kepada kurir karena barang yang dibelinya tidak sesuai, seperti berita seorang ibu dan anaknya yang memaki kurir penghantar barang belanjaannya karena merasa tidak puas dengan kondisi barang yang dibeli lalu menumpahkan kekesalan kepada kurir dan menolak untuk membayar pembeliannya ${ }^{7}$. Kasus lain di Ciputat, tindakan pengancaman, MDS yang merasa tertipu dengan barang yang dibeli lalu meminta uangnya dikembalikan oleh kurir, akan tetapi kurir menolak hingga MDS mengancam dengan pedang kepada kurir tersebut ${ }^{8}$. Kasus di Banten, seorang pria berinisial RA yang mengancam akan memborgol kurir jika tidak segera mengembalikan uangnya. Alasan RA melakukan hal tersebut karena kecewa dengan barang yang dibelinya tidak sesuai ${ }^{9}$. Kasus di Sumatera Barat, seorang Ibu yang mengamuk tidak terima dan meminta uangnya dikembalikan kurir karena barang yang dikirim seharga Rp.10.000. sedangkan barang yang dibeli seharga Rp.115.000. Ibu tersebut sampai membanting barang kiriman lain milik kurir $^{10}$. Hal ini menunjukkan bahwa masyarakat Indonesia belum memahami betul prosedur dan etika dalam melakukan transaksi berbelanja online menggunakan metode pembayaran COD.

\section{Tinjauan Pustaka}

\section{Masyarakat Informasi}

Masyarakat Informasi merupakan konsep yang dikenalkan oleh Daniel Bell pada awal 1970-an tentang masyarakat paska industrial lalu dikembangkan lebih lanjut oleh Manuel Castell dengan mengutarakan pandangannya tentang kemunculan masyarakat, kultur dan ekonomi yang dilihat dari sudut pandang revolusi teknologi informasi. 
Masyarakat informasi adalah masyarakat yang menjadikan kualitas hidup, dan juga prospek perubahan sosial dan pembangunan ekonomi tergantung pada proses produksi, konsumsi, distribusi dan manipulasi informasi menjadi sebuah aktivitas utama sehari-hari. Masyarakat informasi ditandai dengan intensitas yang tinggi atas pertukaran dan pengguanaan teknologi komunikasi .

Metode perbelanjaan online termasuk dalam masyarakat informasi. Dengan kemajuan teknologi dan internet, membuat masyarakat beralih berbelanja melalui internet. Berbelanja online memudahkan masyarakat untuk berbelanja dari mana saja dan kapan saja, asalkan terhubung dengan internet. Masyarakat beralih menjadi berbelanja online juga diakibatkan oleh persepsi manfaat, masyarakat yang menjadi konsumen jika meyakini bahwa berbelanja online akan lebih menguntungkan daripada berbelanja luring, maka konsumen akan memilih untuk berbelanja secara online dalam memenuhi kebutuhannya. ${ }^{13}$

\section{E-commerce}

e-commerce merupakan sebuah produk hasil perkembangan teknologi informasi dan mempengaruhi kehidupan ekonomi dan kultur masyarakat, dalam e-commerce terjadi pertukaran informasi antara penjual dan konsumen di dunia maya. e-commerce membantu melakukan perdagangan konvensional melalui inovasi cara mentransfer dan memproses informasi. Informasi menjadi inti dari semua kegiatan komersial, karena e-commerce mengacu pada pertukaran informasi bisnis menggunakan pertukaran data elektronik yang ditransfer dari komputer ke komputer lain-

${ }^{12} E k a$ A G Wuryanta, 'Literasi Informasi , Masyarakat Dan Media Baru : Wacana Masyarakat Informasi Dan Dinamika Teknologi Media', Jurnal Komunikasi, 2019; Suwarno.

${ }^{13}$ Despina and A. Karayanni, 'Web-Shoppers and Non-Shoppers: Compatibility, Relative Advantage and Demographics', European Business Review, 15.3 (2003), 141-52 < https://doi.org/10.1108/09555340310474640>

${ }^{14}$ Dedy Ansari Harahap and Dita Amanah, 'Perilaku Belanja Online Di Indonesia: Studi Kasus', Jurnal Riset Manajemen Sains Indonesia, 922 (2018), 193-213 < journal.unj.ac.id/unj/index.php/jrmsi/article/view/6005/5876>.

${ }^{15}$ P. Kotler and G. Armstrong, Marketing, 6th edn (New Jersey: Pearson Prentice Hall, 2003).

${ }^{16}$ Britz. nya dengan cara otomatis ${ }^{14}$.

Dengan e-commerce masyarakat Indonesia mengubah kebiasaan yang pada awalnya mencari semua kebutuhan sehari-harinya dengan pergi berbelanja ke pasar atau toko, dengan adanya e-commerce calon konsumen hanya butuh sentuhan jari dan hitungan menit untuk membeli kebutuhannya dan merubah perekonomian masyarakat, yang pada awalnya sering melakukan transaksi tunai, sekarang menjadi non tunai, dan penjual juga dapat memangkas biaya sewa tempat dan menjualkan barangnya dengan lebih mudah melalui e-commerce. Adapun empat faktor yang mempengaruhi berbelanja online menurut Kotler \& Armstrong, yaitu ${ }^{15}$

1. Kenyamanan konsumen yang tidak perlu pergi ke toko secara langsung

2. Kelengkapan informasi yang disediakan oleh e-commerce memungkinkan konsumen untuk mendapatkan informasi dengan mudah, kemudian konsumen dapat memesan informasi di tempat.

3. Tidak terbatas waktu dan lokasi bagi konsumen untuk mendapatkan informasi tentang harga dan memesan barang yang dibutuhkan.

4. Kepercayaan konsumen dalam keamanan pengiriman barang dan kerahasiaan data pribadi seperti kartu kredit.

\section{Kemiskinan Informasi}

Kemiskinan Informasi merupakan sebuah gap atau jarak antara masyarakat yang terjadi karena adanya penggeseran era informasi yang diakibatkan oleh perkembangan teknologi informasi dan komunikasi (TIK) ${ }^{16}$. Kemiskinan Informasi adalah suatu kondisi dimana individu atau masyarakat tidak mempunyai keahlian untuk memahami kebutuhan, menggunakan, menginterpretasikan dan menerapkan informasi secara tepat dalam kehidupan sehari-hari. Miskin informasi adalah suatu permasalahan sosial karena dapat menyebabkan tidak terpenuhinya hak-hak individu 
yang akan berdampak pada kualitas kehidupan. ${ }^{17}$ Karakteristik dari masyarakat informasi yaitu: orang dalam kondisi ekonomi lemah, orang yang tinggal di daerah letak geografisnya membuat sulit mengakses informasi, kemiskinan sosial dan kultural, minoritas, dan disabilitas ${ }^{18}$. Selain itu, ada tiga faktor penyebab terjadinya miskin informasi, ${ }^{19}$ yaitu;

\section{- Faktor Akses Informasi}

Faktor akses informasi merupakan penyebab utama dari kemiskinan informasi karena individu atau masyarakat tidak mampu untuk memanfaatkan informasi dengan tepat, bukan hanya tidak mampu dalam proses pencarian informasi, tetapi juga tidak mampu untuk menentukan nilai produk serta layanan dari informasi tersebut. Seperti halnya banyak sekali informasi yang bisa kita dapatkan dari manapun, akan tetapi banyak masyarakat kita yang langsung percaya dengan informasi yang didapat tanpa menilai dan menelusur apakah informasi tersebut dari sumber yang dapat dipercaya dan akurat atau tidak. Contohnya dalam melihat informasi pada iklan di suatu produk, banyak masyarakat yang tertipu dengan tagline iklan dengan huruf dicetak besar tanpa melihat keterangan lanjutan tentang tagline tersebut. Biasanya pada setiap iklan diberikan tanda bintang (*) yang mengisyaratkan adanya ketentuan tambahan untuk mendapatkan keuntungan yang ditawarkan oleh produk yang diiklankan.

\section{- Faktor Sosial Ekonomi dan Infrastruktur Informasi}

Globalisasi merupakan alasan dari faktor terjadinya kemiskinan informasi, hal ini karena

${ }^{17}$ Himayah, 'Miskin Informasi Merupakan Sebuah Gap Atau Jarak Antara Masyarakat Yang Terjadi Karena Adanya Penggersaran Era Informasi Yang Diakibatkan Oleh Perkembangan Teknologi Informasi Dan Komunikasi (TIK)', Khizanah Al- Hikmah Jurnal Ilmu Perpustakaan, Informasi, Dan Kearsipan, 1.2 (2013), 115-21.

${ }^{18}$ Amalia Nurma Dewi, 'Kemiskinan Informasi Pada Komunitas X', in Integrasi Pustakawan Menuju Masyarakat Informasi: Suatu Perpektif SosialBudaya, ed. by Ike I Lawalanda (Jakarta: Sagung Seto, 2015), pp. 127-44. produk dan layanan informasi di era globalisasi menjadi di komersialisasikan dengan adanya hukum hak intelektual. Sedangkan yang menguasai informasi lebih sering adalah negara maju, hal ini membuat negara kaya menjadi makin kaya karena dapat menghasilkan informasi-informasi baru dari sebuah penelitian, dan negara berkembang sulit untuk maju karena tidak memiliki infrastruktur informasi yang canggih seperti negara maju.

\section{- Faktor Pemahaman Individu}

Faktor ini diakibatkan karena adanya perbedaan kemampuan pemahaman dari setiap individu dalam menilai suatu informasi dari sumber yang sama dapat dimaknai berbeda bagi beberapa orang, tergantung tingkat kemampuan masing-masing individu. Pemahaman seorang Ibu Rumah Tangga pasti akan berbeda dengan Ibu yang bekerja, letak geografis tempat tinggal, dan jenjang pendidikan juga akan mempengaruhi kemampuan memahami informasi. Kemampuan pemahaman masyarakat yang tinggal di Ibukota akan berbeda dengan pemahaman masyarakat desa.

\section{Metode Penelitian}

Penelitian kualitatif adalah sebuah proses penelitian ilmiah dengan tujuan untuk memahami makna dan menggambarkan permasalahan atau fenomena yang dihadapi manusia dalam konteks sosial dan budaya, seperti perilaku, persepsi, tindakan, dan sebagainya ${ }^{20}$. Tujuan dari penelitian dengan metode kualitatif adalah menggali nilai yang terkandung dalam suatu perilaku ${ }^{21}$.Artikel ini menggunakan pendekatan kualitatif dengan metode kajian budaya. Kajian budaya atau da-

\footnotetext{
${ }^{19}$ Himayah.

${ }^{20}$ Sudaryono, Metodologi Penelitian: Kuantitatif, Kualitatif, Dan Mix Method, 2nd edn (Depok: Rajawali Pers, 2019).

${ }^{21}$ Sudaryono.

${ }^{22}$ Septiawan Santana K, Menulis Ilmiah: Metode Penelitian Kualitatif, 1st edn (Jakarta: Yayasan Obor Indonesia, 2007).

${ }^{23}$ K. Azizah, 'Memaki Dan MENGANCAM KURIR COD, Ternyata Ini Sosok Asli Emak-Emak Dalam Video', Merdeka.Com, 2021 <https://www. merdeka.com/trending/memaki-dan-mengancam-kurir-cod-ternyata-inisosok-asli-emak-emak-dalam-video.html?page $=1>$.
} 
pat disebut dengan cultural studies adalah metode yang dikembangkan sebagai metode kritikal kritik untuk analisis, interpretasi dan kritisisme dalam kebudayaan atau kultural ${ }^{22}$, amatlah penting untuk mempelajari bagaimana memahami, menginterpretasi dan mengkritisi berbagai makna dan pesan yang dibuat oleh media. Metode ini dipilih karena tujuan dari artikel ini untuk menggali perilaku dan persepsi masyarakat yang mengalami kesenjangan budaya dalam transaksi pembelian online dengan menggunakan metode pembayaran COD.

Pengambilan data dalam penelitian ini melalui kajian literatur berupa buku, artikel jurnal, berita, dan sumber lain yang dapat dipercaya. Literatur yang terjaring dalam artikel ini sebanyak 14 artikel berita yang didapat dari portal berita online yang terbit pada tahun 2021, dan 15 literatur ilmiah dengan periode tahun terbit dari 2007-2020.

\section{Hasil dan Pembahasan}

\section{Permasalahan Pembelian dan Pengiriman}

Maraknya pembelian dari e-commerce dengan metode pembelian COD pada tahun 2021 yang bertujuan untuk mempermudah transaksi berbelanja online ternyata menimbulkan permasalahan baru. Beberapa konsumen salah memahami pembayaran COD. Pada tahun 2021 ditemukan 12 berita dari portal berita online yang viral $\mathrm{di}$ masyarakat. Tujuh berita menggambarkan penolakan konsumen dalam melakukan proses pembayaran dengan metode COD karena barang yang diantarkan tidak sesuai, empat berita meng-

\footnotetext{
${ }^{24}$ 'Vira.'

${ }^{24}$ 'Viral, Emak-Emak Di Pasaman Barat Maki Kurir Belanja Online ${ }^{25}$ Sari

${ }^{26}$ Sihombing.

${ }^{27}$ Dominique Hilvy Febiani, 'Viral! Pria Ini Ngamuk Dan Ancam Memborgol Kurir Saat COD', Okezone.Com, 2021 <https://nasional.okezone.com/ read/2021/06/16/337/2426362/viral-pria-ini-ngamuk-dan-ancam-memborgol-kurir-saat-cod.>

${ }^{28}$ M.Andimaz Kahfi, 'Tak Ngerti Beli COD, Pria Ini Ngotot Buka Barang Pesanan Baru Bayar, Setelahnya Ini Yang Terjadi', Tribun-Medan. Com, $2021<$ https://medan.tribunnews.com/2021/02/09/tak-ngerti-belicod-pria-ini-ngotot-buka-barang-pesanan-baru-bayar-setelahnya-ini-yangterjadi?page $=3>$.

${ }^{29}$ Dythia Novianty, 'Pembeli COD Ini Ngamuk Dan Rendahkan Kurir, Bikin Warganet Emosi', Suara.Com, $2021<$ https://www.suara.com/ tekno/2021/09/13/100500/pembeli-cod-ini-ngamuk-dan-rendahkan-kurir-
} bikin-warganet-emosi > gambarkan konsumen meminta dengan kasar kepada kurir untuk mengembalikan uang mereka dan mengembalikan paket kepada kurir dan satu berita menggambarkan konsumen memaksa untuk membuka paket terlebih dahulu sebelum membayar kepada kurir.

Adapun bila dilihat dari gender, lebih banyak pria dalam berita viral tersebut. terdapat tujuh pria dan enam wanita dalam berita yang viral di masyarakat karena memarahi kurir dan menolak membayar kurir COD.

Tabel 1 Data berita permasalahan pembelian online

\begin{tabular}{|c|c|c|c|}
\hline No & $\begin{array}{l}\text { Judul artikel/ } \\
\text { judul berita }\end{array}$ & Permasalahan & $\begin{array}{l}\text { Sumber } \\
\text { berita }\end{array}$ \\
\hline 1 & $\begin{array}{l}\text { Memaki dan } \\
\text { Mengancam }\end{array}$ & $\begin{array}{l}\text { Konsumen menolak } \\
\text { membayar pembelian }\end{array}$ & $\begin{array}{l}\text { merdeka. } \\
\text { com }\end{array}$ \\
\hline & $\begin{array}{l}\text { Kurir COD, } \\
\text { Ternyata ini } \\
\text { Sosok Asli } \\
\text { Emak-Emak } \\
\text { dalam Video } \\
\text { (lokasi: } \\
\text { Kebon Jeruk, } \\
\text { Jakarta } \\
\text { Barat) }\end{array}$ & $\begin{array}{l}\text { COD kepada Kurir } \\
\text { karena barang yang } \\
\text { diantar tidak sesuai } \\
\text { dengan yang dibeli. } \\
\text { Selain menolak, } \\
\text { Konsumen memaki dan } \\
\text { memarahi kurir COD } \\
\text { dengan kasar. }\end{array}$ & \\
\hline 2 & $\begin{array}{l}\text { Viral Emak- } \\
\text { Emak di } \\
\text { Pasaman } \\
\text { Barat Maki } \\
\text { Kurir } \\
\text { Belanja } \\
\text { Online } \\
\text { COD }^{24} \\
\text { (lokasi: } \\
\text { kabupaten di } \\
\text { Sumatera } \\
\text { Barat) }\end{array}$ & $\begin{array}{l}\text { Barang yang di terima } \\
\text { tidak sesuai, Konsumen } \\
\text { memintar uang } \\
\text { dikembalikan dengan } \\
\text { kasar kepada kurir COD }\end{array}$ & iNews.id \\
\hline
\end{tabular}


Adista Nurfitria, Laksmi

Dampak Kemiskinan Informasi Masyarakat Dalam Transaksi Berbelanja Online

\begin{tabular}{|c|c|c|c|}
\hline 3 & $\begin{array}{l}\text { Pria di } \\
\text { Ciputat } \\
\text { Ancam Kurir } \\
\text { COD dengan } \\
\text { Pedang } \\
\text { Karena } \\
\text { Merasa } \\
\text { Ditipu, Beli } \\
\text { Jam tapi } \\
\text { dapat Kardus } \\
\text { Kosong } \\
\\
\text { Lokasi: } \\
\text { Kampung } \\
\text { Parung } \\
\text { Benying, } \\
\text { Serua, } \\
\text { provinsi } \\
\text { banten) }\end{array}$ & $\begin{array}{l}\text { Setelah proses } \\
\text { pembayaran pembelian } \\
\text { COD dengan kurir } \\
\text { selesai, Konsumen } \\
\text { membuka paket yang } \\
\text { diterima, jam tangan } \\
\text { yang dibeli tidak ada. } \\
\text { Hal ini membuat } \\
\text { Konsumen merasa } \\
\text { tertipu dan memaksa } \\
\text { dan mengancam kurir } \\
\text { dengan pedang untuk } \\
\text { mengembalikan } \\
\text { uangnya. }\end{array}$ & $\begin{array}{l}\text { kompas.c } \\
\text { om }\end{array}$ \\
\hline 4 & $\begin{array}{l}\text { Todong } \\
\text { Kurir Barang } \\
\text { Pakai Pistol, } \\
\text { Pria di Bogor } \\
\text { Ditangkap. } \\
\\
\text { (Lokasi: } \\
\text { Tenjolaya, } \\
\text { Bogor) }\end{array}$ & $\begin{array}{lr}\text { Konsumen } & \text { membuka } \\
\text { paket COD yang di beli } \\
\text { sebelum melakukan } \\
\text { transaksi pembayaran } \\
\text { kepada kurir, setelah } \\
\text { dibuka, warna sandal } \\
\text { yang dibeli tidak sesuai, } \\
\text { Konsumen menolak } \\
\text { membayar ran } \\
\text { mengancam dris } \\
\text { dengan pistol karena } \\
\text { kurir terus meminta } \\
\text { Konsumen untuk } \\
\text { membayar paket yang } \\
\text { telah dibuka tersebut. }\end{array}$ & $\begin{array}{l}\text { kompas.c } \\
\text { om }\end{array}$ \\
\hline 5 & $\begin{array}{l}\text { Viral! Pria } \\
\text { Ini Ngamuk } \\
\text { dan Ancam } \\
\text { Memborgol } \\
\text { Kurir saat } \\
\text { COD }^{27}\end{array}$ & $\begin{array}{l}\text { Konsumen meminta } \\
\text { mengembalikan } \\
\text { uangnya secara paksa } \\
\text { dengan mencaci maki } \\
\text { dan mengancam } \\
\text { memborgol kurir. hal ini } \\
\text { terjadi karena barang } \\
\text { yang diterima tidak } \\
\text { sesuai dan kualitas } \\
\text { barangnya tidak sesuai } \\
\text { ekspektasi Konsumen. }\end{array}$ & $\begin{array}{l}\text { nasional. } \\
\text { okezone. } \\
\text { com }\end{array}$ \\
\hline 6 & $\begin{array}{l}\text { Tak Ngerti } \\
\text { Beli COD, } \\
\text { Pria Ini } \\
\text { Ngotot Buka } \\
\text { Barang } \\
\text { Pesanan } \\
\text { Baru Bayar, } \\
\text { Setelahnya } \\
\text { Ini Yang } \\
\text { Terjadi }^{28} \\
\text { (Lokasi: } \\
\text { Bengkulu) }\end{array}$ & $\begin{array}{l}\text { Konsumen memaksa } \\
\text { membuka terlebih } \\
\text { dahulu paket yang dibeli } \\
\text { sebelum membayar. } \\
\text { Setelah di buka, barang } \\
\text { tidak sesuai dengan } \\
\text { pesanan dan Konsumen } \\
\text { menolak membayar dan } \\
\text { memarahi kurir. }\end{array}$ & $\begin{array}{l}\text { medan.tri } \\
\text { bunnews. } \\
\text { com/ }\end{array}$ \\
\hline
\end{tabular}

${ }^{30}$ Novianty.

${ }^{31}$ Tasmalanda, 'Marah-Marah Dan Kasar Pada Kurir COD, Emak Ini Bikin Netizen GeramNo Title', Suara.Com, $2021<$ https://sumsel.suara. $\mathrm{com} / \mathrm{read} / 2021 / 09 / 03 / 101708 / \mathrm{marah}$-marah-dan-kasar-sama-kurir-codemak-ini-bikin-netizen-geram?page $=$ all $>$.

${ }^{32}$ Riki Chandra, 'Heboh! Emak-Emak Di Padang Maki-Maki Kurir COD, Minta Uang Dikembalikan', Suara.Com2, 2021 <https://sumbar.suara.com/ read/2021/06/09/162253/heboh-emak-emak-di-padang-maki-maki-kurircod-minta-uang-dikembalikan>.

\begin{tabular}{|c|c|c|c|}
\hline 7 & $\begin{array}{l}\text { Pembeli } \\
\text { COD Ini } \\
\text { Ngamuk dan } \\
\text { Rendahkan } \\
\text { Kurir, Bikin } \\
\text { Warganet } \\
\text { Emosi }^{29} \\
\text { (Lokasi: } \\
\text { Pasar } \\
\text { Minggu) }\end{array}$ & $\begin{array}{l}\text { Konsumen memaksa } \\
\text { untuk membuka paket } \\
\text { terlebih dahulu sebelum } \\
\text { membayar biaya COD } \\
\text { kepada kurir. }\end{array}$ & $\begin{array}{l}\text { suara.co } \\
\mathrm{m}\end{array}$ \\
\hline 8 & $\begin{array}{l}\text { Lagi, Kurir } \\
\text { Dimaki } \\
\text { Bapak- } \\
\text { Bapak Tak } \\
\text { Mau Bayar } \\
\text { Transaksi } \\
\text { COD }{ }^{30} \\
\text { (Lokasi: }_{\text {Solok, }} \\
\text { Sumatera } \\
\text { Barat) }\end{array}$ & $\begin{array}{l}\text { Konsumen memaksa } \\
\text { untuk memeriksa paket } \\
\text { yang dibeli. Ternyata } \\
\text { bonus yang dijanjikan } \\
\text { berupa tas dan topi tidak } \\
\text { ada di dalam paket. Hal } \\
\text { ini yang membuat } \\
\text { Konsumen marah dan } \\
\text { menolak membayar } \\
\text { kurir dengan mengusir } \\
\text { kurir untuk pergi dari } \\
\text { rumahnya. }\end{array}$ & $\begin{array}{l}\text { iNews.co } \\
\mathrm{m}\end{array}$ \\
\hline 9 & $\begin{array}{l}\text { Marah- } \\
\text { marah dan } \\
\text { Kasar pada } \\
\text { Kurir COD, } \\
\text { Emak Ini } \\
\text { Bikin } \\
\text { Netizen } \\
\text { Geram }{ }^{31} \\
\text { (Lokasi: } \\
\text { Palembang) } \\
\end{array}$ & $\begin{array}{l}\text { Konsumen menolak } \\
\text { membayar paket COD } \\
\text { yang diantarkan oleh } \\
\text { kurir dengan alasan, } \\
\text { Konsumen merasa } \\
\text { sudah membatalkan } \\
\text { pembelian melalui } \\
\text { aplikasi. }\end{array}$ & $\begin{array}{l}\text { sumsel.s } \\
\text { uara.com }\end{array}$ \\
\hline 10 & $\begin{array}{l}\text { Heboh! } \\
\text { Emak-emak } \\
\text { di Padang } \\
\text { Maki-maki } \\
\text { Kurir COD, } \\
\text { Minta Uang } \\
\text { Dikembalika } \\
\mathrm{n}^{32} \\
\text { (Lokasi: } \\
\text { Padang) }\end{array}$ & $\begin{array}{l}\text { Barang yang dibeli tidak } \\
\text { lengkap, membuat } \\
\text { Konsumen memaksa } \\
\text { kurir } \\
\text { mengembalikan untuk } \\
\text { pembelian. }\end{array}$ & $\begin{array}{l}\text { suara.co } \\
\mathrm{m}\end{array}$ \\
\hline 11 & $\begin{array}{l}\text { PASUTRI } \\
\text { Ini Aksinya } \\
\text { Bikin } \\
\text { Geram, } \\
\text { Kurir yang } \\
\text { Antar Paket } \\
\text { Diusir, Tak } \\
\text { Mau Bayar } \\
\text { Belanjaan } \\
\text { COD } 33 \\
\text { (Lokasi: } \\
\text { Mandala, } \\
\text { Kota } \\
\text { Medan.) } \\
\end{array}$ & $\begin{array}{l}\text { Konsumen menolak } \\
\text { membayar kepada kurir } \\
\text { dan mengusir kurir } \\
\text { secara kasar karena } \\
\text { barang yang diterima } \\
\text { tidak sesuai. }\end{array}$ & $\begin{array}{l}\text { palemba } \\
\text { ng.tribun } \\
\text { news.co } \\
\text { m }\end{array}$ \\
\hline 12 & $\begin{array}{l}\text { Terjadi Lagi, } \\
\text { Ibu-ibu } \\
\text { Kabur Usai } \\
\text { Buka Paket } \\
\text { saat COD, } \\
\text { Ngotot Tak } \\
\text { Mau Bayar } \\
\text { karena } \\
\text { Sempit }{ }^{34} \\
\text { (Lokasi: }_{\text {tidak }} \\
\text { diketahui) }\end{array}$ & $\begin{array}{l}\text { Konsumen membuka } \\
\text { paket terlebih dulu, } \\
\text { setelah dicoba barang } \\
\text { yang dibelinya tidak } \\
\text { sesuai, Konsumen } \\
\text { menolak membayar } \\
\text { barang tersebut kepada } \\
\text { kurir dan memilih untuk } \\
\text { menghindari kurir }\end{array}$ & $\begin{array}{l}\text { indozone } \\
\text { id }\end{array}$ \\
\hline
\end{tabular}




\section{Lemahnya Pengetahuan Konsumen}

Maraknya temuan permasalahan konsumen yang memarahi kurir karena kecewa akan barang yang didapat, menggambarkan lemahnya pengetahuan konsumen akan berbelanja online dengan metode pembayaran COD. Konsumen menyalahkan kurir yang kewajibannya hanya mengantarkan barang dari penjual kepada konsumen dan menganggap bahwa kurir adalah penjual. Konsumen kurang memahami hak dan kewajibannya dalam proses berbelanja secara online. Karena ketidaktahuan konsumen, akhirnya meluapkan kekecewaan kepada pihak yang salah yaitu kurir, bukan kepada penjual.

Pembayaran dengan metode COD menjadi popular semenjak peralihan perilaku belanja dari berbelanja langsung atau secara luring, menjadi online atau daring di masa pandemi. Ignatius Untung yang merupakan seorang pengamat $e$ commerce, mengatakan bahwa sistem pembayaran COD memang diciptakan untuk menyasar masyarakat dengan literasi digitalnya masih kurang, khususnya literasi berbelanja online. Konsumen tidak mengetahui bahwa metode COD memiliki tingkat keamanan lebih rendah daripada metode pembayaran escrow ${ }^{35}$. Escrow adalah salah satu jasa pembayaran perantara yang digunakan oleh e-commerce ${ }^{36}$. Jasa pembayaran escrow menjadi pihak ketiga yang menjembatani penjual dengan konsumen. Metode escrow akan menampung uang dari konsumen, dan akan memberikan kepada penjual jika barang sudah diterima dengan baik oleh konsumen dan menjamin segala transaksi penjualan telah dibayarkan konsumen. Metode pembayaran escrow membuat penjual dan konsumen aman da-

${ }^{33}$ Rahmaliyah, 'PASUTRI Ini Aksinya Bikin Geram, Kurir Yang Antar Paket Diusir, Tak Mau Bayar Belanjaan COD', Palembang.Tribunnews.Com, $2021<$ https://palembang.tribunnews.com/2021/11/25/pasutri-ini-aksinyabikin-geram-kurir-yang-antar-paket-diusir-tak-mau-bayar-belanjaan-cod > ${ }^{34}$ Putri Octapia Saragih, 'Terjadi Lagi, Ibu-Ibu Kabur Usai Buka Paket Saat COD, Ngotot Tak Mau Bayar Karena Sempit', Indozone.Id, 2021.

${ }^{35}$ Wahyunanda Kusuma Pertiwi, 'Banyak Menuao Masalah, Seberapa Siap Masyarakat Dengan Sistem COD', Kompas.Com, 2021 <tekno.kompas.com/read/2021/06/07/15030077/banyak-menuai-masalah-seberapasiap-masyarakat-dengan-sistem-cod-?page $=$ all $>$. lam melakukan transaksi belanja online melalui e-commerce.

Dari berbagai contoh kasus pengancaman kurir COD oleh konsumen pembelian e-commerce, Sebagian besar letak geografis tempat tinggal konsumen berada di daerah, Sembilan dari 12 kasus tentang perselisihan antara konsumen dan kurir COD berada di kawasan jauh dari pusat pertumbuhan atau di desa. Letak geografis konsumen akan mempengaruhi sosial ekonomi konsumen, yang akan berhubungan dengan tingkat pemahaman informasi. Masyarakat yang tinggal di kota atau di kawasan sekitar pusat pertumbuhan akan mendapatkan aksesibilitas yang akan mempengaruhi tingginya tingkat pendidikan dan pendapatan masyarakat tersebut, sebaliknya masyarakat yang bertempat tinggal jauh dari kawasan pusat pertumbuhan atau di desa memiliki tingkat pendidikan dan pendapatan yang lebih rendah dibandingkan dengan masyarakat perkotaan ${ }^{37}$.

Maraknya kasus konsumen e-commerce yang mengamuk kepada kurir COD menunjukkan masih minimnya pengetahuan masyarakat terhadap transaksi secara digital yang dimiliki oleh masyarakat. sejumlah pelanggan dengan sistem COD sekadar memahami bahwa mereka membayar saat telah menerima barang yang dipesan. Masyarakat tidak mengetahui bahwa kewajiban dan tanggung jawab dari kurir hanyalah sebatas mengantarkan barang pesanan pelanggan diterima dalam keadaan utuh tanpa kerusakan, bukan isi dari paket pesanannya. Dan jika barang pesanan tidak sesuai, pelanggan dapat menghubungi penjual. Pihak e-commerce akan menindaklanjuti melalui bagian costumer care bila antara kedua belah pihak tidak menemukan kesepakatan ${ }^{38}$.

Adapun syarat dan ketentuan pembayaran COD dari pihak e-commerce Shoppe ${ }^{39}$, tokopedia ${ }^{40}$, bliblii $^{41}$, lazada ${ }^{42}$, dan bukalapak ${ }^{43}$ yang tercantum pada bagian help center atau bantuan dalam kategori pembayaran COD yang dapat dilihat melalui website masing-masing $e$ commerce memiliki kesamaan ketentuan, yaitu; 
1. Pengiriman paket COD hanya dapat dilakukan oleh pihak ekspedisi yang sudah ditunjuk oleh pihak e-commerce.

2. Konsumen tidak diperbolehkan membuka paket sebelum membayar biaya pembelian yang ditagihkan kepada kurir.

3. Jika paket pembelian tidak sesuai, dapat melakukan pengembalian barang dengan ketentuan pengembalian barang pembelian sesuai dengan ketentuan masing-masing e-commerce dan tidak dapat menitipkan kembali kepada kurir.

\section{Minimnya Edukasi dari Pihak e-Commerce}

Banyaknya temuan permasalahan tentang pembelian online dengan metode pembayaran COD, membangun pertanyaan "apakah konsumen telah diberikan pengetahuan akan perbelanjaan dengan metode pembayaran COD?". Faktanya, informasi tentang metode pembayaran COD tidak dilakukan secara eksplisit. Biaya produksi iklan yang mahal menjadi salah satu alasan mengapa e-commerce tidak secara lengkap menjabarkan informasi. Seperti iklan tentang metode COD milik Shoppe, bintang iklan hanya menari dan bernyanyi mengatakan "Shoppe COD, Shoppe COD, langsung bayar di tempat. Shoppe COD, Shoppe COD, pasti gratis ongkir". Dalam iklan tidak dijelaskan dengan lengkap bagaimana ketentuan yang ideal dalam melakukan transaksi berbelanja online dengan menggunakan metode pembayaran COD.

Informasi tentang ketentuan pembayaran COD bukanlah hal yang wajib dibaca langsung saat konsumen memilih metode pembayaran COD. Hal ini membuat besar kemungkinan konsumen tidak membaca terlebih dahulu ketentuan yang

${ }^{36}$ Mary Anne Patton, 'Technologies for Trust in Electronic Commerce', Electronic Commerce Research, 4.1-2 (2004), 9-21 <https://doi. org/10.1023/B:ELEC.0000009279.89570.27>

${ }^{37}$ U. Farida, 'Pengaruh Aksesibilitas Terhadap Karakteristik.', Jurnal Wilayah Dan Lingkungan., 1.1 (2013), 49-66.

${ }^{38}$ T.R. Simanjuntak, 'Marak Kurir COD Diperlakukan Buruk Oleh Pelanggan Adalah Bukti Masyarakat Belum Paham Transaksi Digital', 2021.

${ }^{39}$ Shoppe, 'Shopeehelpcenter'. ideal saat memilih metode pembayaran COD ini.

\section{Kebijakan Pemerintah}

Selain kurangnya pengetahuan konsumen dan kurangnya penyebaran literasi dari pihak e-commerce mengenai transaksi berbelanja online, belum adanya regulasi yang dijadikan dasar hukum atau regulasi tentang transaksi berbelanja online juga menjadi alasan maraknya kasus kekecewaan konsumen. Hal ini di dukung oleh Bima Laga, Ketua Asosiasi E-Commerce Indonesia (idEA), Bima Laga menghimbau pemerintah untuk membuat regulasi mengenai transaksi berbelanja online $e^{44}$.

Peraturan yang telah dibuat oleh pemerintah saat ini hanya mengatur perdagangan saja, seperti PP No 80 Tahun 2019 tentang Perdagangan Melalui Sistem Elektronik, didalamnya belum terkandung peraturan-peraturan dengan metode yang terbaru seperti metode pembayaran COD Karena itu, konsumen belum terlindungi dengan sepenuhnya dalam transaksi berbelanja online.

\section{Kesimpulan dan Saran}

Dampak dari miskin informasi dalam berbelanja online melalui e-commerce adalah adanya gap atau ketimpangan pengertian dari pembelian menggunakan metode pembayaran COD. Masyarakat hanya sebatas memahami bahwa berbelanja dengan metode pembayaran $\mathrm{COD}$ berarti konsumen dapat membayar barang belanjaannya di rumah konsumen melalui kurir saat kurir datang, masyarakat tidak memahami lebih lanjut bahwa ada ketentuan lain dalam melakukan pembayaran COD seperti konsumen tidak diperbolehkan membuka paket sebelum membayar biaya tagihan kepada kurir dan jika barang tidak sesuai atau memiliki keluhan terhadap ba-

\footnotetext{
${ }^{40}$ Tokopedia.com, 'Tokopedia Care: Syarat Dan Ketentuan Bayar Di Tempat.'

${ }^{4}$ Blibli.com, 'COD (Bayar Di Tempat),', Blibli.Com.

'Lazada, 'Pusat Bantuan: Pembayaran: Lazada ID.

${ }^{43}$ Bukalapak.com, 'Tanya Jawab - Cara Menggunakan Fitur Cash on DELIVERY (COD),

${ }^{44}$ Danang Sugianto, 'COD Banyak Masalah, Pertahankan Atau Hilangkan?', Finance.Detik.Com, 2021 <https://finance.detik.com/berita-ekonomibisnis/d-5579634/cod-banyak-masalah-pertahankan-atau-hilangkan>
} 
rang yang dibeli, konsumen tidak diperbolehkan meminta pengembalian barang melalui kurir tetapi harus mengajukan pengembalian barang dengan ketentuan pengajuan pengembalian barang. Hal ini juga dikarenakan minimnya edukasi tentang transaksi berbelanja online, khususnya edukasi bagi konsumen.

Minimnya penyebaran informasi dari pihak e-commerce kepada konsumen tentang metode transaksi berbelanja online dan belum sempurnanya peraturan dari pemerintah juga menjadi faktor tingginya tingkat kekecewaan konsumen akan pengalaman berbelanja online melalui $e$ commerce. Saran untuk menanggulangi permasalahan Saran yang dapat diberikan untuk menanggulangi kemiskinan informasi transaksi berbelanja online yaitu memberikan edukasi tentang produk dan layanan yang disediakan oleh e-commerce. Dalam menyebarkan edukasi, media sosial seperti youtube atau Instagram dapat menjadi referensi. Akan tetapi informasi harus dikemas secara lengkap, padat, jelas dan menarik untuk dilihat. Kesediaan pemerintah untuk membuat regulasi terkait berbelanja online juga dapat menjadi usaha menanggulangi kemiskinan informasi yang ada. Dengan edukasi yang baik dari segala pihak yaitu seluruh pelaksana e-commerce akan melancarkan transaksi bisnis yang dijalankan. Jika masyarakat Indonesia sudah memahami informasi tentang syarat dan ketentuan dari pembayaran COD, maka akan terpenuhinya hak-hak konsumen dan antara penjual, konsumen, dan kurir tidak ada yang merasa dirugikan.

\section{Referensi}

Azizah, K., 'Memaki Dan MENGANCAM KURIR COD, Ternyata Ini Sosok Asli Emak-Emak Dalam Video', Merdeka.Com, $2021<$ https:// www.merdeka.com/trending/memaki-danmengancam-kurir-cod-ternyata-ini-sosok-asliemak-emak-dalam-video.html?page $=1>$

Blibli.com, 'COD (Bayar Di Tempat).', Blibli. Com
Britz, Johannes, 'Information Poverty: The Development of a Global Moral', 2010, 9-17

Bukalapak.com, 'Tanya Jawab - Cara Menggunakan Fitur Cash on DELIVERY (COD).'

Chandra, Riki, 'Heboh! Emak-Emak Di Padang Maki-Maki Kurir COD, Minta Uang Dikembalikan', Suara.Com2, 2021 <https://sumbar. suara.com/read/2021/06/09/162253/hebohemak-emak-di-padang-maki-maki-kurir-codminta-uang-dikembalikan>

Despina, and A. Karayanni, 'Web-Shoppers and Non-Shoppers: Compatibility, Relative Advantage and Demographics', European Business Review, 15.3 (2003), 141-52 < https:// doi.org/10.1108/09555340310474640>

Dewi, Amalia Nurma, 'Kemiskinan Informasi Pada Komunitas X', in Integrasi Pustakawan Menuju Masyarakat Informasi: Suatu Perpektif Sosial-Budaya, ed. by Ike I Lawalanda (Jakarta: Sagung Seto, 2015), pp. 127-44

Farida, U., 'Pengaruh Aksesibilitas Terhadap Karakteristik.', Jurnal Wilayah Dan Lingkungan., 1.1 (2013), 49-66

Febiani, Dominique Hilvy, 'Viral! Pria Ini Ngamuk Dan Ancam Memborgol Kurir Saat COD', Okezone.Com, $2021<$ https://nasional.okezone. com/read/2021/06/16/337/2426362/viralpria-ini-ngamuk-dan-ancam-memborgolkurir-saat-cod.>

Hamed, S., El-Deeb, S., 'Cash on Delivery as a Determinant of E-Commerce Growth in Emerging Markets.', Journal of Global Marketing, 33.4 (2020), 242-265.

Harahap, Dedy Ansari, and Dita Amanah, 'Perilaku Belanja Online Di Indonesia: Studi Kasus', Jurnal Riset Manajemen Sains Indonesia, 9.2 (2018), 193-213 <journal.unj.ac.id/ unj/index.php/jrmsi/article/view/6005/5876>

Himayah, 'Miskin Informasi Merupakan Sebuah Gap Atau Jarak Antara Masyarakat Yang Terjadi Karena Adanya Penggersaran Era Informasi Yang Diakibatkan Oleh Perkembangan Teknologi Informasi Dan Komunikasi (TIK)', 
Khizanah Al- Hikmah Jurnal Ilmu Perpustakaan, Informasi, Dan Kearsipan, 1.2 (2013), 115-21

K, Septiawan Santana, Menulis Ilmiah: Metode Penelitian Kualitatif, 1st edn (Jakarta: Yayasan Obor Indonesia, 2007)

Kahfi, M.Andimaz, 'Tak Ngerti Beli COD, Pria Ini Ngotot Buka Barang Pesanan Baru Bayar, Setelahnya Ini Yang Terjadi', Tribun-Medan.Com, $2021<$ https:// medan. tribunnews.com/2021 /02/09/ tak-ngerti-beli-cod-pria-ini-ngotot-buka-barang-pesanan-baru-bayar-setelahnyaini-yang-terjadi?page $=3>$

Kotler, P., and G. Armstrong, Marketing, 6th edn (New Jersey: Pearson Prentice Hall, 2003)

Lazada, 'Pusat Bantuan: Pembayaran: Lazada ID.'

Mou, Xiaobo, 'Examining the Factors in Fl Uencing Information Poverty in Western China', 38.2019 (2020), 1115-34 <https://doi. org/10.1108/EL-04-2020-0095>

Novianty, Dythia, 'Pembeli COD Ini Ngamuk Dan Rendahkan Kurir, Bikin Warganet Emosi', Suara.Com, 2021 <https:/www.suara.com/ tekno/2021/09/13/100500/pembeli-cod-iningamuk-dan-rendahkan-kurir-bikin-warganet-emosi>

Patton, Mary Anne, 'Technologies for Trust in Electronic Commerce', Electronic Commerce Research, 4.1-2 (2004), 9-21 <https://doi. org/10.1023/B:ELEC.0000009279.89570.27>

Pertiwi, Wahyunanda Kusuma, 'Banyak Menuao Masalah, Seberapa Siap Masyarakat Dengan Sistem COD', Kompas.Com, 2021 <tekno. kompas.com/read/2021/06/07/15030077/ banyak-menuai-masalah-seberapa-siapmasyarakat-dengan-sistem-cod-?page $=$ all $>$

Rahmaliyah, 'PASUTRI Ini Aksinya Bikin Geram, Kurir Yang Antar Paket Diusir, Tak Mau Bayar Belanjaan COD', Palembang. Tribunnews. Com, $2021<$ https://palembang.tribunnews. com/2021/11/25/pasutri-ini-aksinya-bikingeram-kurir-yang-antar-paket-diusir-tak-mau- bayar-belanjaan-cod>

Saragih, Putri Octapia, 'Terjadi Lagi, Ibu-Ibu Kabur Usai Buka Paket Saat COD, Ngotot Tak Mau Bayar Karena Sempit', Indozone.Id, 2021

Sari, N., 'Pria Di Ciputat Ancam Kurir COD Dengan Pedang Karena Merasa Ditipu, Beli Jam Tapi Dapat Kardus Kosong.', Kompas.Com, 2021

Septianie, I. \& Wiyata, M.T., 'Pengaruh Kemudahan Dan Kepercayaan Terhadap Niat Pembelian Secara Onlinepada Platform E-CommerceLazada Indonesia.', Winter Journal., 1.1 (2020), 73-83.

Shoppe, 'Shopeehelpcenter'

Sihombing, R., 'Todong Kurir Barang Pakai Pistol, Pria Di BOGOR DITANGKAP.', 2021

Simanjuntak, T.R., 'Marak Kurir COD Diperlakukan Buruk Oleh Pelanggan Adalah Bukti Masyarakat Belum Paham Transaksi Digital', 2021

Sudaryono, Metodologi Penelitian: Kuantitatif, Kualitatif, Dan Mix Method, 2nd edn (Depok: Rajawali Pers, 2019)

Sugianto, Danang, 'COD Banyak Masalah, Pertahankan Atau Hilangkan?', Finance.Detik. Com, $2021<$ https://finance.detik.com/berita-ekonomi-bisnis/d-5579634/cod-banyakmasalah-pertahankan-atau-hilangkan >

Sugihartati, R., Perkembangan Masyarakat Informasi Dan Teori Sosial Kontemporer. (Jakarta: Kencana, 2014)

Suwarno, Wiji, Pengetahuan Dasar Kepustakaan (Bogor: Ghalia Indonesia, 2010)

Tasmalanda, 'Marah-Marah Dan Kasar Pada Kurir COD, Emak Ini Bikin Netizen GeramNo Title', Suara.Com, $2021<$ https://sumsel.suara.com/ read/2021/09/03/101708/marah-marah-dankasar-sama-kurir-cod-emak-ini-bikin-netizengeram?page $=$ all $>$

Tokopedia.com, 'Tokopedia Care: Syarat Dan Ketentuan Bayar Di Tempat.'

'Viral, Emak-Emak Di Pasaman Barat Maki Kurir 
Belanja Online COD.', 2021

Wedhaswary, I. D., '). Kasus Kurir COD Dimaki Konsumen, Apa Yang Harus Diperbaiki?', 2021

Wuryanta, EkaAG, 'Literasi Informasi, Masyarakat
Dan Media Baru : Wacana Masyarakat Informasi Dan Dinamika Teknologi Media', Jurnal Komunikasi, 2019 